\title{
Investigating the Effect of Internal Marketing on Employee Happiness in University of Isfahan
}

\author{
Mohammad Hassan Tanhaei \\ Department of Management, Islamic Azad University, Najafabad Branch, Najafabad ,Iran
}

\author{
Dr. Ali Nasr Isfahani
}

Assistant Professor, Department of Management, University of Isfahan

\section{Dr. Majid Nili Ahmadabadi}

Department of Management, Islamic Azad University, Najafabad Branch, Najafabad, Iran

DOI: $\quad 10.6007 /$ IJARBSS/v3-i9/216 URL: http://dx.doi.org/10.6007/IJARBSS/v3-i9/216

\begin{abstract}
Internal marketing seeks to enhance employees' satisfaction as internal customers of the corporation. Therefore, its purpose is continuous improvement in offering the products and services across the corporation. In this regard internal marketing can be considered as an enhancer which creates an attractive workplace for employees. Attractive workplace is defined as creating a climate that gives rise to happiness for employees. And employees' happiness is finally resulted in their fulfillment. In this study, the effect of internal marketing on employee happiness is investigated.

This survey was conducted using descriptive-field method. It was carried out in University of Isfahan. The statistical population included 910 employees of the university. Field methods and questionnaire were used to gather essential information. Data were gathered through two standard questionnaires of internal marketing (Rafiq \& Ahmad) and happiness (Oxford). Reliability of the questionnaire was obtained by means of Cronbach's alpha coefficient that was equal to 0.97 and 0.95 for internal marketing and happiness respectively. Validity of the questionnaire was confirmed implicitly but face validity was applied for more confidence. SPSS and Amos were used to analyze data descriptively, assess the credibility of the model and test hypotheses. Results indicated that the main hypothesis under the heading "internal marketing affects employee happiness" was confirmed. Also all sub-hypotheses entitled aspects of internal marketing (internal product, pays, place, and internal promotion) have a positive effect on employee happiness.
\end{abstract}

Keywords: Internal Marketing, Happiness, Pays, Internal product, place, Internal promotion 


\section{Introduction}

Human resources are the most valuable asset of organization. Therefore, organizations undertake to cost high for employees. This is due to employee satisfaction that results in developing the quality of products and services as well as achieving customer satisfaction Internal marketing pursues to increase the satisfaction of employees as the internal customers of organization. So the goal is to improve offering services and products to customers continuously. Extensive studies approved the positive relationship between internal marketing and many organizational components such as loyalty, job satisfaction and performance. Therefore, internal marketing can be defined as a promoter which establishes an attractive workplace for employees. An attractive workplace is defined as creation the atmosphere which brings happiness to staff. Ultimately employee happiness leads to their flourishing (Vasconcelos, 2008). Caruana and Calleya (1998) argued that the purpose of internal marketing is to establish the situation in which the awareness of employees increases. Chang and Kelly (1994) stated that the improvement and satisfaction of internal consumer must have priority to satisfying each consumer out of organization. On the other hand, Piercy and Morgan (1991) stated that the goal of internal marketing is associated with external marketing plan. Internal marketing is used for reaching to the higher level of job satisfaction. This satisfaction gives internal consumers (employees) the sense of happiness due to their working experience. As mentioned, if internal customers are the largest asset of company, organizations should establish the situation in which their needs are satisfied and the best employees are kept. Since happiness in life is a goal for human beings, the task of organization is to apply it as a strategy for keeping and provoking its best asset. Ling (1999) claimed that internal marketing must establish the situation in organization which makes the employees happy. Brum (1998) also mentioned that the main output of internal marketing`s programs creates a happy environment for staff and any kind of organization has the ability to create it. Hence, the present study analyzes the effect of internal marketing and its aspects on employee happiness.

Internal marketing

Barry et al. (1981) for the first time introduced the aspects of internal marketing based on traditional 4Ps (product, price, promotion and place) of traditional marketing in America. They assumed that employees as customers and their businesses as products can be considered. Also, Flipo (1981), based on 4Ps elements in external marketing, explained internal marketing as: products as a job, prices as the cost of employment opportunities in the work, place as the location where jobs are offered near the place of residence of internal consumers, and promotion as communication and reward system. In the following table, the proportion of each elements of traditional and internal marketing is shown. 
Table 1. Comparison of internal marketing and external marketing mix(Ahmed and Rafiq; 1995)

\begin{tabular}{|l|l|}
\hline $\begin{array}{l}\text { Internal marketing } \\
\text { mix }\end{array}$ & External marketing mix \\
\hline Internal product & Product \\
\hline Pays & Price \\
\hline Internal promotion & Promotion \\
\hline Workplace & Place \\
\hline
\end{tabular}

Gounaris (2008) stated that internal marketing's preface is based on two major parts: first, before satisfying customers' needs, employees ' needs must be satisfied, then the rules which is executed in trade market must be used in internal marketing similarly. Hung and Lin(2008) argued that most businesses can't develop and execute internal marketing strategies due to the lack of knowledge and different understanding of the components of internal marketing. Based on other researchers 'findings Hernandez and Sanchez (2008) stated that there aresignificant relationship between internal marketing and organizationalperformance. With a little reflection, it seems that internal marketing is associated with a significant number of management technologies such as human resource management, employee relations, strategic management, organizationalcommunications and macro marketing (Varey, 2000). Hence, internal marketing is defined as the chain which connects all sectors of intra-organization. Therefore, internal marketing can eliminate or reduce the sources of discontent. The goal of internal marketing is to develop the programs of internal marketing for intra-organization consumers simultaneous with execution of external marketing programs (Kale, 2006).

The basic concept of internal marketing is special attention toward employees of allorganizational levels as internal customers (Gronroos, 2001). Emphasizing on the importance of employees' roles caused service organizations pay more attention to adopt internal marketing and treat employees as domestic customers (Mishra, 2010).

Many studies have shown that internal marketing has positive effect on job satisfaction (Ahmed et al., 2003; Hwang and Chi, 2005). Some researchers believe that to carry out internal marketing successfully, employees should tend to support and follow plans (Roberts-Lombard, 2010). The preparation of external marketing is the successful application of internal marketing principles in the organization (Johnson and Scott, 2006).

Happiness

From long time ago, people have been looking for this issue how to live better and what mechanisms can provide happiness. Happiness is a feeling that people experience after achieving their goals. When used in this sense, it is synonymous with life quality (Veenhoven, 2006). Happiness is a mental feeling that every healthy human feels it throughout his life (Vasconcelos, 2008). Those who know the value of life will evaluate the positive of life. Sheldon et al. (2002) argued that the probability of outward and inward flowering of happy people is 
very high.Research shows that happy employees enjoy several advantages more than their colleagues who are less happy. People who work in a happy environment have higher social skills, reach an agreement in case of inter-conflicts and eventually have more intimate relationship with others. Furthermore, there is more probability that people with higher mental healthshow higher efficiency and performance to supervisors and achieve better management jobs. Researchers' findings suggested that happy people show less maltreatment and fatigue (Frisch et al., 2004). In addition, happy people are retained in their jobs. Much evidence found that happy people experience greater satisfaction (Connolly \& Viswesvaran, 2000). When a person acquires job happiness, Likelihood of success is very high. Happy people are evaluated higher than their colleagues by appraisers (Staw et al., 1994). Moreover, as mentioned, happy people enjoy their life, indeed they experience higher quality of life.

Positive Psychology

Positivist psychology is the novel field in psychology. It seeks to express the image of good life clearly in order to determine what is worth for living; it uses the experimental methods of psychology. The aim is to show what action result in experiencing happiness, raising positivelooking people who are flexible, and creating innovative and efficient organization. Positive psychology mainly pays attention to strengthen individual abilities and suitability. Therefore, the main subject of positive psychology is to study positive mental experiences such as pleasure, satisfaction, joy, hope, optimism, competence, perseverance ,interpersonal skills, creativity, initiative, interpersonal responsibility, work conscience, and interest in working. The famous American psychologist, Martin Seligman who raised the theory of "learned optimism", in his book, i.e. "real happiness" explained how psychology in its history course, lost the way and only pay attention to unwell aspects instead of positive points of human characteristics Seligman believed that happiness is the alienable right of every human being that they must plan and try to achieve it. According to him, real happiness is not only unachievable but also it is the fact that makes the life enhanced and causes the human relations enriched. Thus, it is recommended that managers apply positive psychology to obtain happy environment.

Figure 1. Conceptual model (1)

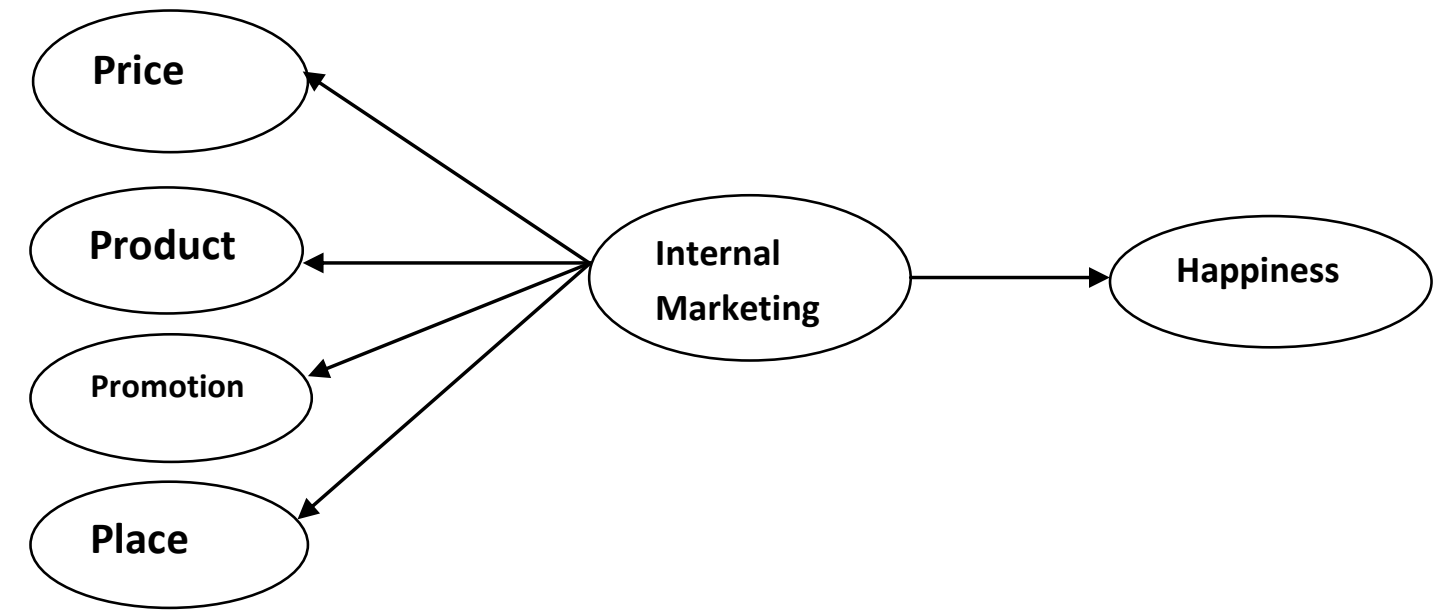

Hypotheses

Based on conceptual model the main hypothesis is: 
1) Internal marketing has a positive impact on employee happiness.

Sub - Research hypotheses are:

2) Price has a positive impact on employee happiness.

3) Product has a positive impact on employee happiness.

4) Promotion has a positive impact on employee happiness.

5) Place has a positive impact on employee happiness.

\section{Methodology}

This survey was conducted using descriptive-field method. It was carried out in University of Isfahan. The statistical population included 910 employees of the university. Field methods and questionnaire were used to gather essential information. Data were gathered through two standard questionnaires of internal marketing (Rafiq \& Ahmad) and happiness (Oxford). Reliability of the questionnaire was obtained by means of Cronbach's alpha coefficient that was equal to 0.97 and 0.95 for internal marketing and happiness respectively. Validity of the questionnaire was confirmed implicitly but face validity was applied for more confidence. In this study, 230 questionnaires were randomly distributed among the employees in the university. Eventually 225 questionnaires were returned. SPSS and Amos were used to analyze data descriptively, assess the credibility of the model and test hypotheses. Results indicated that the main hypothesis under the heading "internal marketing affects employee happiness" was confirmed.

\section{Data Analysis}

Test the main hypothesis research

With the first hypothesis partial regression coefficients corresponding index values are given in the table below.

Table 2.Regression coefficients and hypothesis tests

\begin{tabular}{|c|r|r|c|c|c|c|}
\hline $\begin{array}{c}\text { Hypothes } \\
\text { is }\end{array}$ & \multicolumn{2}{|c|}{ Hypothesis } & C.R & Regression coefficients & P & $\begin{array}{c}\text { Test } \\
\text { Result }\end{array}$ \\
\hline 1 & $\begin{array}{r}\text { Happines } \leftarrow \\
\text { S }\end{array}$ & $\begin{array}{r}\text { Internal } \\
\text { Marketing }\end{array}$ & $\begin{array}{c}7.2 \\
4\end{array}$ & 0.857 & 0.00 & $\begin{array}{c}\text { Suppor } \\
\text { t }\end{array}$ \\
\hline
\end{tabular}

Main Hypothesis) Internal Marketing has a positive impact on employee happiness Standardized regression coefficient for this hypothesis, 0.85 , which is the $P$ value of the regression coefficient of less than 0.05 is concluded that the hypothesis with 0.95 is accepted so Internal Marketing has a positive impact on employee happiness 


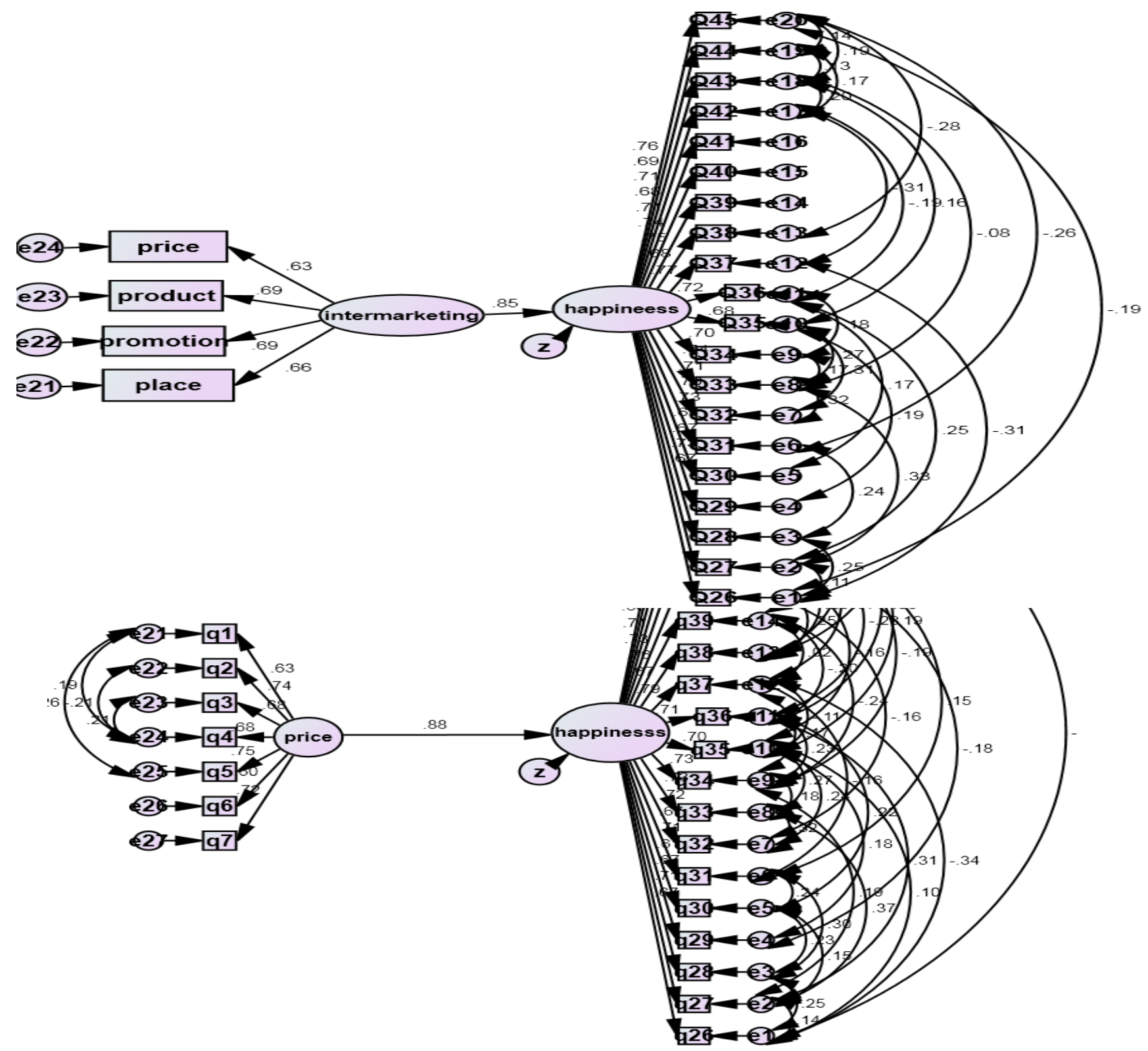

Figure 3: Structural equation model of Promotion on employee happiness

Table4: Regression coefficients (test hypotheses 1-1)

\begin{tabular}{|c|c|c|c|c|c|c|c|}
\hline Hypothes & \multicolumn{3}{|c|}{ Hypothesis } & C.R & Regression coefficients & $\mathbf{P}$ & $\begin{array}{c}\text { Test } \\
\text { Result }\end{array}$ \\
\hline 2 & $\begin{array}{r}\text { Happines } \\
s\end{array}$ & $\leftarrow$ & Price & $\begin{array}{c}8.3 \\
8\end{array}$ & 0.88 & $\begin{array}{r}/ 000 \\
0\end{array}$ & $\begin{array}{c}\text { Suppor } \\
t\end{array}$ \\
\hline
\end{tabular}

- test of sub-research hypotheses 


\section{Secondary Hypothesis 1-1)Price has a positive impact on employee happiness}

Standardized regression coefficient for this hypothesis, 0.88 , which is the $P$ value of the regression coefficient of less than 0.05 is concluded that the hypothesis with 0.95 is accepted so Price has a positive impact on employee happiness

Table5: general fit indices for structural equation modeling analysis, hypothesis 1-2

\begin{tabular}{ccccccc}
\hline CMIN/DF & $P$ & GFI & RMR & IFI & CFI & RMSEA \\
$1 / 70$ & $0 / 000$ & $0 / 87$ & $0 / 06$ & $0 / 93$ & $0 / 93$ & $0 / 066$
\end{tabular}

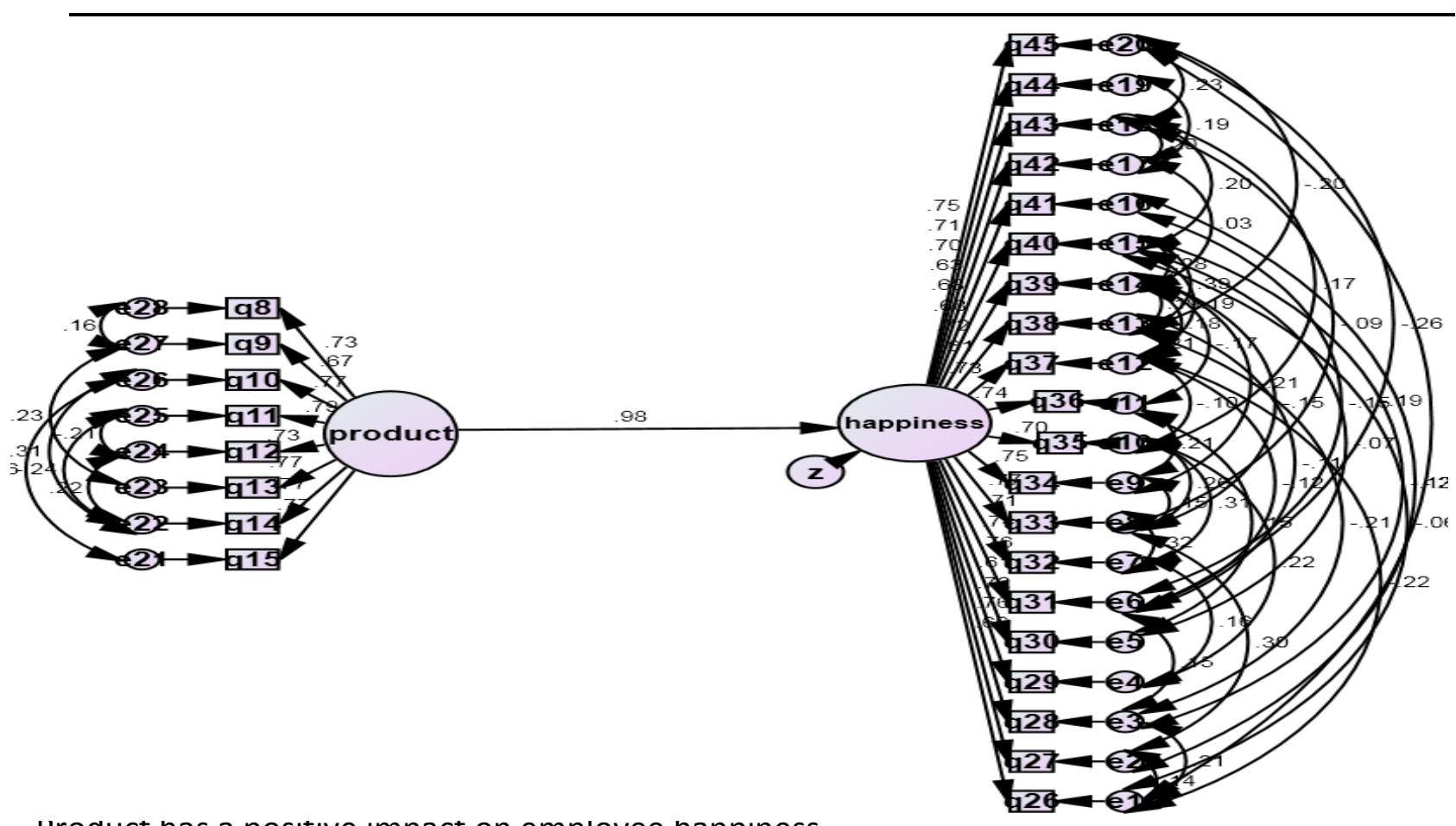

Product has a posıtıve ımpact on employee happıness

\begin{tabular}{|c|c|c|c|c|c|c|c|}
\hline Hypothes & Hyp & oth & & C.R & Regression coefficients & $\mathbf{P}$ & Test \\
\hline 3 & $\begin{array}{r}\text { Happines } \\
\text { s }\end{array}$ & $\leftarrow$ & Product & $\begin{array}{c}10.0 \\
3\end{array}$ & 0.97 & $\begin{array}{r}/ 000 \\
0\end{array}$ & $\begin{array}{c}\text { Suppor } \\
t\end{array}$ \\
\hline
\end{tabular}

indices for structural equation modeling analysis, hypothesis 1-3 


\begin{tabular}{ccccccc}
\hline CMIN/DF & $P$ & GFI & RMR & IFI & CFI & RMSEA \\
$1 / 60$ & $0 / 000$ & $0 / 88$ & $0 / 06$ & $0 / 94$ & $0 / 94$ & $0 / 06$ \\
\hline
\end{tabular}

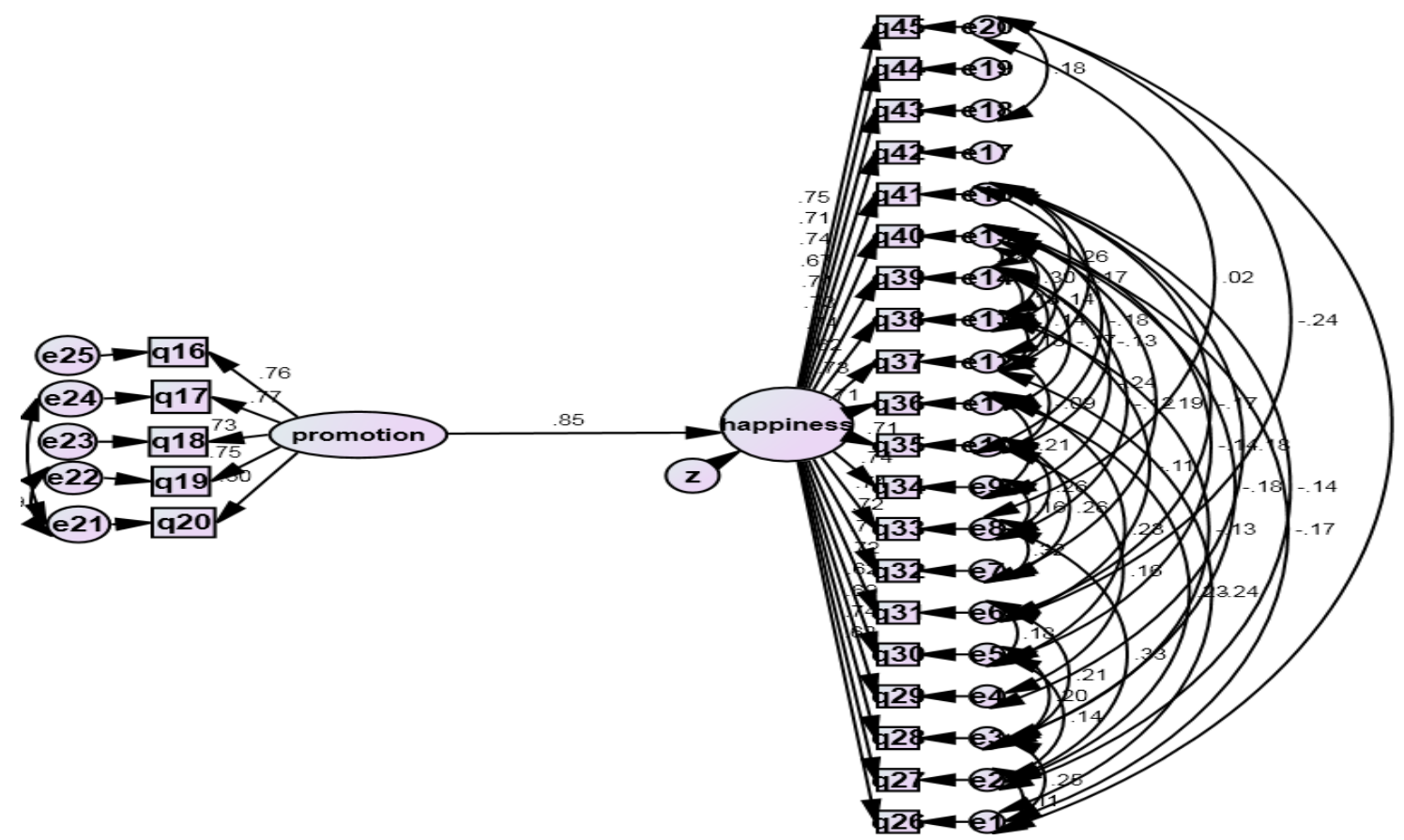

\begin{tabular}{|c|r|r|r|c|c|c|c|}
\hline $\begin{array}{c}\text { Hypothes } \\
\text { is }\end{array}$ & \multicolumn{2}{|c|}{ Hypothesis } & C.R & Regression coefficients & P & $\begin{array}{c}\text { Test } \\
\text { Result }\end{array}$ \\
\hline 4 & $\begin{array}{r}\text { Happines } \\
\text { s }\end{array}$ & $\leftarrow$ & $\begin{array}{r}\text { Promotio } \\
\mathrm{n}\end{array}$ & $\begin{array}{l}6.6 \\
7\end{array}$ & 0.84 & $\begin{array}{c}\text { /000 } \\
0\end{array}$ & $\begin{array}{c}\text { Suppor } \\
\text { t }\end{array}$ \\
\hline
\end{tabular}

Secondary Hypothesis 1-3)Promotion has a positive impact on employee happiness Standardized regression coefficient for this hypothesis, 0.80 , which is the $P$ value of the regression coefficient of less than 0.05 is concluded that the hypothesis with 0.95 is accepted so Promotionhas a positive impact on employee happiness. 
Table 9: general fit indices for structural equation modeling analysis, hypothesis 1-4

$\begin{array}{ccccccc}\text { CMIN/DF } & P & \text { GFI } & \text { RMR } & \text { IFI } & \text { CFI } & \text { RMSEA } \\ 1 / 50 & 0 / 000 & 0 / 89 & 0 / 07 & 0 / 95 & 0 / 95 & 0 / 05\end{array}$

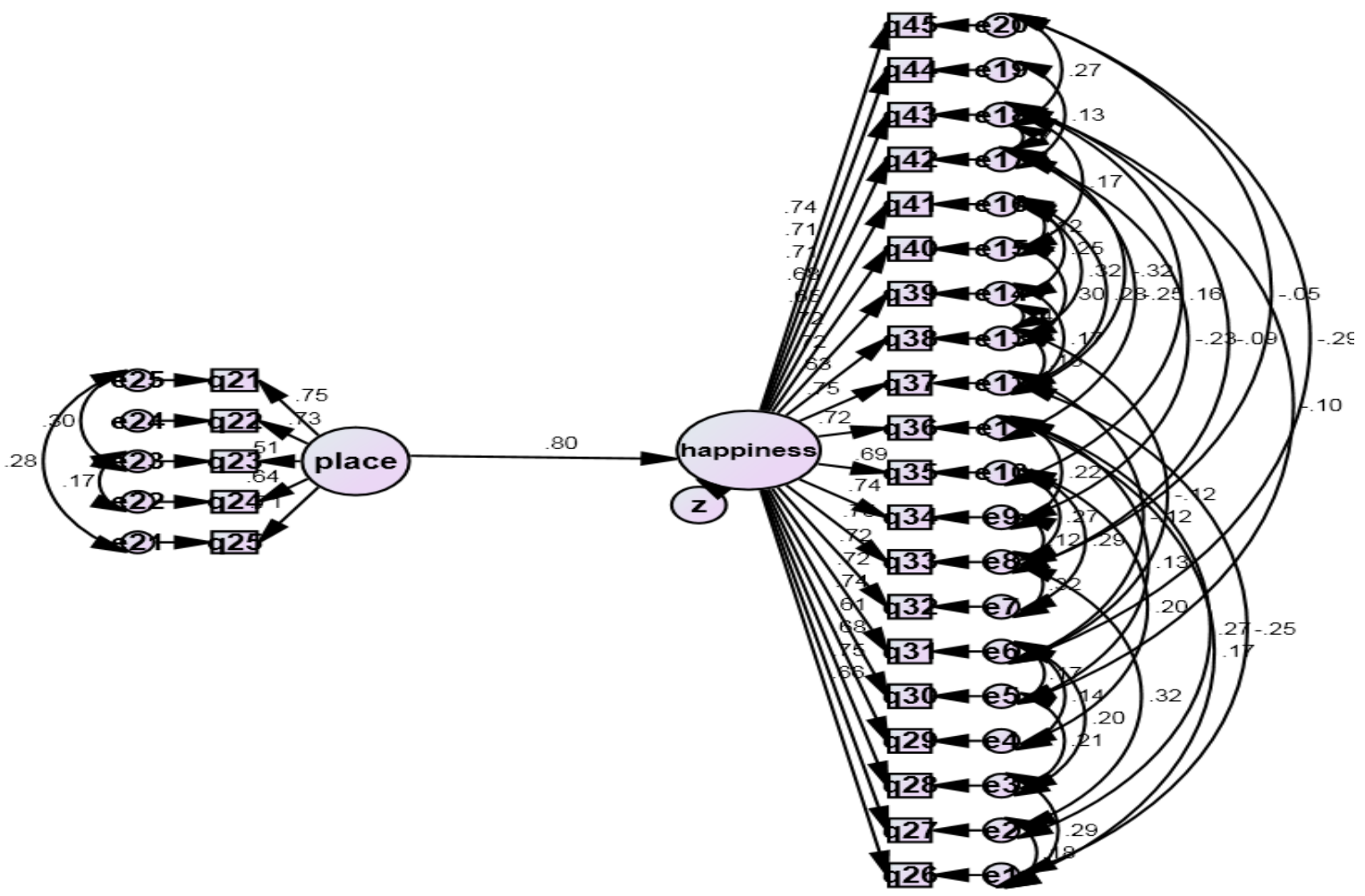

\begin{tabular}{|c|c|c|c|c|c|c|c|}
\hline Hypothes & \multicolumn{3}{|c|}{ Hypothesis } & C.R & Regression coefficients & $\mathbf{P}$ & $\begin{array}{c}\text { Test } \\
\text { Result }\end{array}$ \\
\hline 5 & $\begin{array}{r}\text { Happines } \\
\text { s }\end{array}$ & $\leftarrow$ & Place & $\begin{array}{c}7.1 \\
4\end{array}$ & 0.80 & $\begin{array}{r}/ 000 \\
0\end{array}$ & $\begin{array}{c}\text { Suppor } \\
t\end{array}$ \\
\hline
\end{tabular}

Secondary Hypothesis 1-4) Place has a positive impact on employee happiness

Standardized regression coefficient for this hypothesis, 80/0, which is the $P$ value of the regression coefficient of less than 05/0 is concluded that the hypothesis with $95 / 0$ is accepted so Place has a positive impact on employee happiness

\section{Conclusion and Result}

It is assumed that one of the biggest concerns of organization is to establish happy working environment. Therefore, if both marketing and human resources management work together, they can offer happiness to internal customers of organization. The purpose of this study was also to examine the impact of internal marketing on staff happiness. The aspects of internal marketing (attractive internal products, good pays, effective internal promotion, and happy 
workplace) can be considered and measured. Thus, in this research the impact of internal marketing on staff happiness as the main hypothesis is analyzed. The main hypothesis was confirmed by positive and strong effect. The result confirmed the conclusion of previous researchers that internal marketing causes mental health and happiness.

In this study, there were minor hypotheses. Given that internal marketing includes four aspects, the effects of each aspect on employee happiness was studied separately. Findings showed that the second hypothesis based on the effect of pays on employee happiness was approved; therefore, payment has positive and significant impact on employee happiness. The third hypothesis suggested that there was significant relationship between internal product and happiness, so it had impact on employee happiness. Fourth and fifth hypothesis which analyzed the impact of internal promotion and workplace on employee happiness were approved with reliability at level 0.95 .

Organizations must never forget this fact that domestic customers (employees) turn the future events of organization. Therefore, if organizations want their employees to survive in the market, they should revise their behaviors and attitudes toward them.As previously mentioned, employees are the most valuable asset of organizations, so they pay a huge amount of money for recruitment. What should be taken into consideration is the role of managers and management tools to grant the needs of employees and their loyalty toward organization.

Management tools for creating a happy environment by marketing approaches include:

To give priority employees in the organization

To develop a career widely as a product

Strong communication as a major source of happiness

To improve team working and collaborative activities.

\section{Recommendation}

Due to extensive changes in business environment, organizations need to increase the level of quality and quantity of their products. Thus, to achieve this important issue, paying attention to employees as internal customers who have a key role in the organization, are required. Therefore, motivating employees and improving services, enhancing spirits, and keeping employees happy cause them to participate in work tasks. Consequently it helps organization to provide products with higher quality. The chain eventually leads to increase satisfaction and loyalty of external customer of organization.

\section{References}

Vasconcelos, A, F. (2008). "Broadening even more the internal marketing concept", European Journalof Marketing, Vol. 42 No. 11/12, 2008 pp. 1246-1264

Caruana, A. and Calleya, P. (1998). "The effect of internal marketing on organizational commitmentamong retail bank managers", The International Journal of Bank Marketing, Vol. 16 No. 3, pp. 108-16.

Chang, R.Y. and Kelly, P.K. (1994). Satisfying Internal Customers First!, Richard Chang, Irvine, CA. 
Piercy, N. and Morgan, N. (1991). "Internal marketing - the missing half of the marketing programme”, Long Range Planning, Vol. 24 No. 2, pp. 82-93.

Lings, I.N. (1999). "Balancing internal and external market orientations", The Research Institute Research Paper Series, RP9912, Aston Business School, Aston, October.

Berry, L.L. and Parasuraman, A. (2000). "Services marketing starts from within", in Varey, R.J. andLewis, B.R. (Eds), Internal Marketing: Directions for Management, Routledge, London, pp. 173-91.

Flipo, J.P. (1986). "Service firms: interdependence of external and internal marketing strategies", European Journal of Marketing, Vol. 20 No. 8, pp. 5-14.

Rafiq, M. and Ahmed, P.K. (1995). Using the 7Ps as a generic marketing mix: an exploratory survey

of UK and European marketing academics, Marketing Intelligence and Planning; Vol. 13, No. 9, pp. $4-15$.

Gounaris, S. (2008). "The notion of internal market orientation and employee job satisfaction: some preliminary evidence", Journal of Services Marketing, 22(1):68-90.

Hung JY, Lin TY (2008). The Investigation on the Internal Marketing Practicing of the International Tourism Hotel Chains. J. Int. Manage. Stud. February pp. 170-176.

Sanchez-Hernandez, M.I. (2008). "Internal marketing as a factor of success in new service development: An empirical approach", International review on public and non profit marketing, 5: 81-82.

Varey, R.J. (2000). "A broader conception of internal marketing: a social constructionist perspective", in Varey, R.J. and Lewis, B.R. (Eds), Internal Marketing: Directions for Management, Routledge, London, pp.

281-90.

Kale SH (2006). Internal Marketing: An Antidote for Macau's Labor Shortage. UNLV Gaming Res. Rev. J. 11(1): 1-11.

Gronroos, C. (2001). Service Management and Marketing, 2nd edition, Chichester: John Wiley \& Sons Ltd.

Mishra S, (2010). Internal marketing - A tool to harness employees' power in service organizations in India. Int J Bus Manag, 5(1):185-193.

Ahmed PK, Rafiq M (2003). Internal marketing issues and challenges. Eur. J. Market. 37(9): 1177-1186. 
Hwang IS, Chi DJ, (2005). Relationships among internal marketing, employee job satisfaction and international hotel performance: An empirical study. Int J Manag, 22(2):285-93.

Roberts-Lombard, M, (2010). African Journal of Business Management Vol. 4(4), pp. 362-372. Herington. C, Johnson. W, Scott. D, (2006). European Business Review Vol. 18 No. 5, pp. 364381.

Veenhoven, (2006). Paper presented at conference on 'New Directions in the Study of Happiness.

Sheldon, K.N., Lyubomirsky, S. and Schkade, D. (2002). "Pursuing happiness: the architecture of sustainable change", working paper, University of Texas, Austin, TX.

Frisch, M. B., Clark, M. P., Rouse, S. V., Rudd, M. D., Paweleck, J. K.Greenstone, A., et al. (2004). Predictive and treatment validity of lifesatisfaction and the Quality of Life Inventory. Assessment, 10, 1-13.

Connolly, J.J. and Viswesvaran,C. (2000). 'The Role of Affectivity in Job Satisfaction:A Meta Analysis', Personality and Individual Differences, vol. 29, pp. 265-281.

Staw, B. M., Sutton, R. I., \& Pelled, L. H. (1994). Employee positiveemotion and favorable outcomes at the workplace. Organization Science,5, 51-71. 